DOI 10.37882/2223-2974.2021.02.06

\title{
ОБ ОСОБЕННОСТЯХ ЗАКОНОДАТЕЛЬНОГО РЕГУЛИРОВАНИЯ УСТУПКИ ПРАВ В ИМУЩЕСТВЕННЫХ ОБЯЗАТЕЛЬСТВАХ
}

\section{ON THE FEATURES OF LEGISLATIVE REGULATION ASSIGNMENT OF RIGHTS IN PROPERTY OBLIGATIONS}

\section{A. Gudkov \\ A. Krasilschikov \\ V. Mishchenko}

Summary: In this article, the authors consider one of the pressing problems of legislative regulation in the field of entrepreneurial activity - the assignment of rights in property obligations, analyze the content of the assignment agreement, the conditions for its validity and invalidity, the risks faced by the assignee, assignor and debtor. Noting the constructive role of judicial practice in regulating this sphere of legal relations, the authors emphasize the need for further legislative improvement of the assignment of rights, and set out their proposals on this issue.

Keywords: property obligations, creditor, debtor, bankruptcy, assignment of rights, cession agreement.

\author{
Гудков Анатолий Иванович \\ К.ю.н., дочент, ВЮИ ФСИН России, \\ gudkovaniv@yandex.ru \\ Красильщиков Анатолий Владимирович \\ К.ю.н., дочент, ВЮИ ФСИН России \\ krasilschikov@inbox.ru \\ Мищенко Вячеслав Иванович \\ К.ф.н., дочент, ВЮИ ФСИН России, \\ vyacheslav-mischenko@mail.ru
}

Аннотация: В настоящей статье авторы рассматривают одну из актуальных проблем законодательного регулирования в сфере предпринимательской деятельности - уступу прав в имущественных обязательствах, анализируют содержание договора цессии, условия его действительности и недействительности, риски, с которыми сталкиваются цессионарий, цедент и должник. Отмечая конструктивную роль судебной практики в регулировании данной сферы правоотношений, авторы подчеркивают необходимость дальнейшего законодательного совершенствования уступки прав, излагают свои предложения по данному вопросу.

Ключевые слова: имущественные обязательства, кредитор, должник, банкротство, уступка прав, договор цессии.

вания: задолженности по хозяйственным договорам и займовым распискам, требования об уплате налогов или иных обязательных платежей, кредиторская задолженность, иные имущественные требования.

Уступка требований является популярным инструментом передачи прав в делах о банкротстве, когда один из кредиторов переуступает третьему лицу право требования к должнику. Соответственно в деле выносится определение о перемене лиц в обязательстве и замене первоначального кредитора [1]. Стоит отметить, что уступка права требования допускается неограниченное количество раз, поэтому конечный цессионарий не всегда может быть известен должнику. С этой целью законодатель обязал стороны уведомлять должника о смене кредитора. К тому же у последнего закреплено право возражения на замену кредитора в определенных случаях.

Особенности правового регулирования закреплены в Постановлении Пленума Верховного Суда РФ от 21.12.2017 г. № 54 «О некоторых вопросах применения положений главы 24 ГК РФ о перемене лиц в обязательстве на основании сделки». В частности, законодатель указывает, что форма передачи прав может осуществляться как продажа или дарение прав. То есть, предусматривается платная и бесплатная формы расчетов при 
заключении договора цессии. При этом законодатель не исключает смешанную форму договора или заключение его в силу определенного законодательного акта. Относительно объема передаваемых прав важно отметить, что законодатель предусматривает возможность уступки частичного объема прав либо переуступки всех, в том числе будущих прав, которые возникают в законном порядке, например, при возникновении дополнительных требований по Закону о защите прав потребителей, либо требований по неустойке. Кроме того, следует учитывать, что дополнительные требования могут передаваться цессионарию, как и основные, либо вместе с ними [3].

Договор цессии подлежит регистрации, если объектом перехода прав является недвижимое имущество или права, подлежащие регистрации по закону. В частности, если происходит переуступка прав арендных платежей по договору аренды, заключенному более чем на один год, то цессия подлежит регистрации в Росреестре [2]. Договор цессии влечет полный переход прав и обязанностей по договору с момента его заключения, поэтому цессионарий обязан уплачивать налоги и содержать имущество, в том числе нести расходы по содержанию совместного имущества.

Переход права по договору цессии может осуществляться как в момент заключения сделки, так и с отсрочкой. При этом такое условие должно прописываться в договоре. Обычно такое явление взаимосвязано с переуступкой будущих прав. Данный нюанс является особенностью договора цессии, так как фактически продаются права цедента, которые возникнут в будущем на основании закона. Например, при переуступке прав требования исполнительные документы, поданные ранее цедентом, при исполнительном производстве полностью переходят к цессионарию. Также необходимо иметь в виду, что если цедент передал одно и то же право требования нескольким цессионариям, то надлежащим правопреемником будет являться первый из них. При этом цессионарий, который был лишен права цессии, вправе потребовать от цедента возмещения убытков в полном объеме, которые причинены неисполнением обязательства цедента. Данный нюанс требует от цедента быть предусмотрительным и не заключать договора цессии одновременно с несколькими цессионариями, рассчитывая на более выгодную сделку.

Однако, стоит отличать сам момент перехода настоящих и будущих прав цедента. В частности, при передаче прав по договору займа, срок исполнения по которому еще не наступил, считается, что цедент передал цессионарию настоящие права требования. Например, если договор займа заключен ранее и в момент передачи права принадлежали цеденту в полном объеме, то даже если срок исполнения обязательств заемщика еще не наступил, права могут быть проданы цессионарию. При этом нужно обратить внимание на ответственность цедента, который в полной мере отвечает перед цессионарием за задержку передачи прав в будущем, если она не состоялась или задержалась по каким-либо причинам.

Что касается ответственности цедента, то при заключении договора о переуступке прав необходимо учитывать, что если в процессе реализации прав предмет договора утратит силу, например, окажется, что цедент не имел права на вещь либо она принадлежит иному лицу, то в данном случае цедент не сможет рассчитывать на то, что договор цессии будет недействительным, и в силу положений ГК РФ стороны вернут друг другу причитающееся по сделке. Кроме всего, цеденту придется выплатить цессионарию причиненные убытки, которые возникли в силу прекращения договора цессии и утраты прав цессионария. Иногда затраты цессионария могут оказаться выше, чем стоимость самой цессии по договору переуступки прав.

Также важно рассмотреть случаи никчемности договора цессии и учесть нюансы, которые приводят к его недействительности. В силу ГК РФ некоторые права требования не могут быть переданы цессионарию, если обязательства изначально были связаны с личностью цедента и не могут быть переданы другому лицу в силу условий договора. Законодатель указывает, что по договору обязательство может быть неразрывно связано с личностью кредитора, в таком случае передача прав по цессии возможна только с согласия должника.

Кроме того, стороны цессии не вправе устанавливать взаимосвязь передачи права требования с бесспорностью исполнения цессии, так как в силу законодательства должник вправе оспаривать как договор о переходе права, так и само обязательство, которое переуступлено по договору цессии. Например, должник может оспаривать сумму убытков, обосновывая это тем, что цедент не предпринял должных мер по уменьшению убытков.

В случае, если кредитор и должник договорились о запрете перемены лиц в обязательстве, то в дальнейшем односторонняя переуступка прав требования недопустима без согласия на то должника. В противном случае договор цессии будет являться никчемным и не повлечет переход прав для цессионария.

Следует отметить, что недействительность договора цессии может возникать в силу закона, когда переуступка права требования не допустима и касается личных неимущественных прав цедента. Кроме того, если будет 
установлено, что цессионарий и цедент имели недобросовестные намерения по отношению к должнику и вступили в сговор, чтобы причинить ему вред, такой договор цессии будет считаться недействительным.

В свою очередь, если совершенный переход прав более обременительный или обязательство стало трудно выполнимым для должника, чем первоначальные требования, закон позволяет должнику исполнить обязательство первоначальному кредитору.

Переход права требования обусловлен, с одной стороны, заключением договора цессии, а с другой - уведомлением об этом переходе должника. Закон разрешает уведомление как цессионарием, так и цедентом. Однако, письменное уведомление должно содержать информацию о сумме переуступаемых прав и указание на договор, по которому совершена переуступка.

В свою очередь, должник не лишен права возражать против цессии, если он считает, что его права нарушены или не соблюдены. Отсутствие надлежащего уведомления дает право должнику в целом игнорировать договор цессии и в будущем исполнять обязательство только цеденту. При этом нередко возникают случаи массового перехода прав требования (смена цессионариев), поэтому должник имеет право возразить по каждому переходу прав, опираясь на неправильность оформления цессии или необоснованность перехода.

Верховный Суд РФ разъяснил, что важно правильно направить уведомление должнику, так как в отсутствие уведомления о переходе прав от лица цедента, позволяет должнику не реагировать на уведомление от цессионария, пока первоначальный кредитор не подтвердит такой переход прав [4].

Кроме того, в судебной практике имеется немало случаев, когда исполнение производится первоначальному кредитору, так как уведомление должника не было направлено либо не было им получено. В этом случае закон позволяет цессионарию предъявить требования к цеденту о перечислении ему денежных средств или передаче полученного от должника имущества и имущественных прав.

Таким образом, уступка прав требования является уникальным по своей сути договором, который может иметь смешанную форму и содержать условия, близкие к договору купли-продажи и дарения имущества. Нотариальное оформление цессии не требуется и может осуществляться по взаимному соглашению сторон. Регистрация договора цессии обусловлена сущностью передаваемого права, поэтому зависит от предмета договора и содержания передаваемого обязательства. Исключительность договора цессии заключается в его особенностях по взаимоотношениям с третьей стороной - должником, который участвует в договоре пассивно, но тем не менее, хотя он не является стороной, цессионарий и цедент обязаны соблюдать определенный алгоритм действий по отношению к третьему лицу и учитывать особенности предыдущего договора с должником.

Уступка прав требований - самостоятельный вид договора о переходе прав собственности, подлежащий регистрации в установленных законом случаях. Однако, его условия напрямую зависят не только от волеизъявления сторон, но и иных факторов: возможности надлежащего уведомления должника, отсутствия обременений по согласованию переуступки с должником в силу первоначального договора, наличие законодательного запрета на переуступку и другие нюансы.

В судебной практике нередки случаи, когда цеденты переуступают права требования, которые просрочены в силу истечения срока исковой давности, либо отсутствуют надлежащие документы, подтверждающие задолженность, или может оказаться, что обязательства ранее были исполнены должником путем взаимозачета. Поэтому, приобретая требования за плату, цессионарий подвергается определенному риску, так как затраты на приобретение актива могут не оправдаться, а должник вовсе сможет оспорить данную задолженность, предъявив доказательства своей невиновности. Разумным выходом, на наш взгляд, может быть оплата цессии поэтапно либо после ее признания судом, в том числе должником.

В большинстве случаев переуступка прав требований практикуется в делах о банкротстве лиц, когда первоначальный кредитор утвержден судебным решением и его права не оспариваются. В этом случае цессионарий имеет больше гарантий, что приобретаемые им права будут экономически обоснованы и подлежат бесспорному исполнению. В целом, порядок перехода прав требования требует усовершенствования и единообразия судебной практики. В частности, необходимо установить порядок уведомления должника, который отсутствует по адресу регистрации или место регистрации которого не известно. Например, было бы эффективным законодательным шагом предусмотреть порядок публикации объявления о переходе прав требований в прессе как законный способ уведомления должника. 


\section{ЛИТЕРАТУРА}

1. Федеральный закон "0 несостоятельности (банкротстве)" от 26.10.2002 N 127-Ф3// URL: http://www.consultant.ru/document/cons_doc_LAW_39331/.

2. Федеральный закон "0 государственной регистрации недвижимости" от 13.07.2015 N 218-Ф3 // URL:https:// kad.arbitr.ru/Card/7b1a80b5-d26d-43be-9370963245344588.

3. Постановление Пленума Верховного Суда РФ от 21 декабря 2017 г. N 54 "0 некоторых вопросах применения положений главы 24 Гражданского кодекса Российской Федерации о перемене лиц в обязательстве на основании сделки" // URL: http://base.garant.ru/71843584/.

4. Обзор судебной практики разрешения споров, связанных с установлением в процедурах банкротства требований? контролирующих должника и аффилированных с ним лиц, утвержденный Президиумом Верховного Суда Российской Федерации от 29.01.2020 г.

๑ Гудков Анатолий Иванович (gudkovaniv@уandex.ru), Красильщиков Анатолий Владимирович (krasilschikov@inbox.ru),

Мищенко Вячеслав Иванович (vyacheslav-mischenko@mail.ru).

Журнал «Современная наука: актуальные проблемы теории и практики»
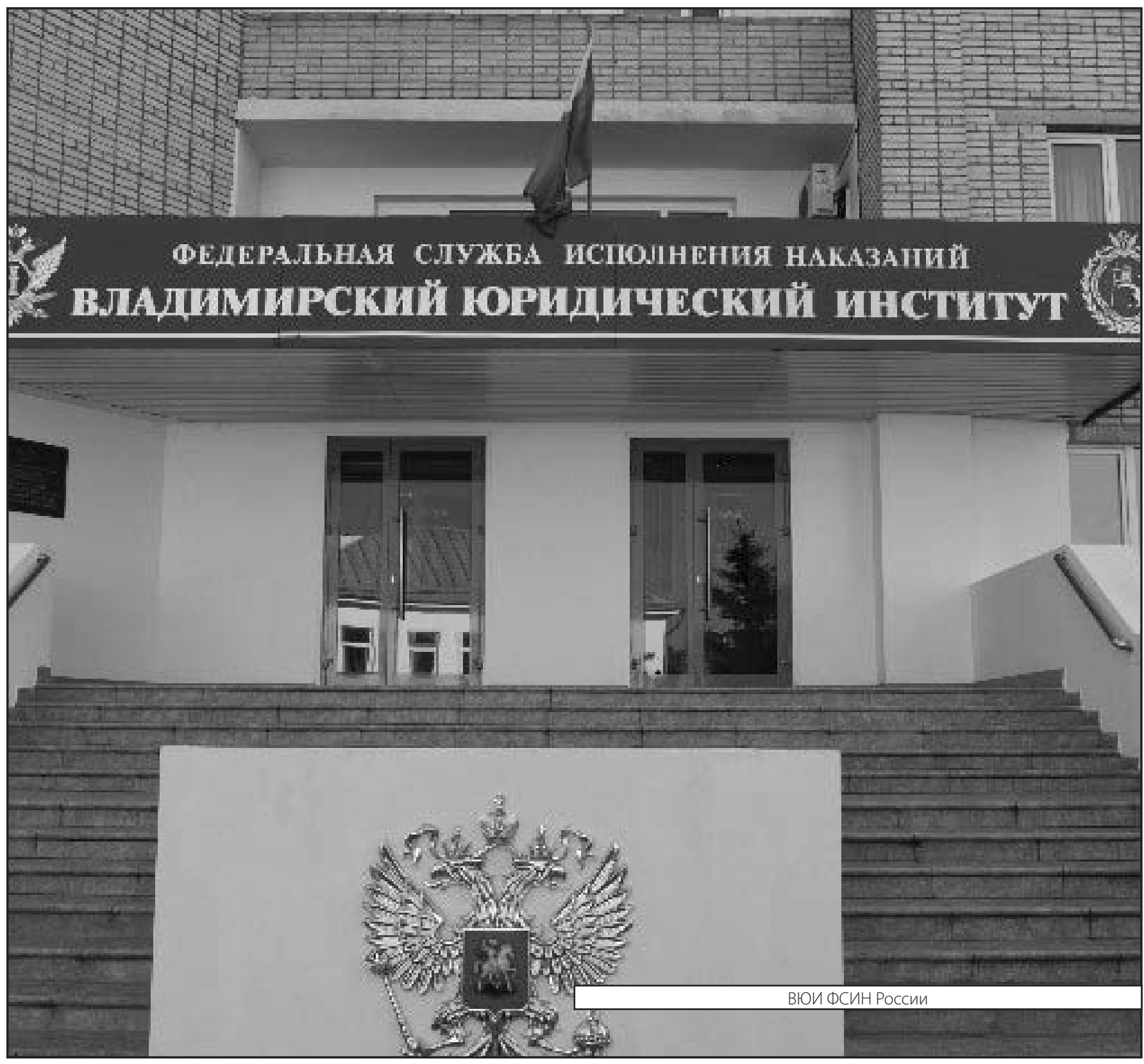